Vol. 7, No. 1, 2021

Solomiya Husak

\title{
CHURCH OF THE DISCALCED CARMELITES IN LVIV AND ARCHITECTURAL STYLE
}

\author{
Master Graduate of the Department of Art History \\ University of Vienna, Vienna \\ e-mail: solomia_husak@yahoo.com \\ orcid: 0000-0002-7922-7405
}

Received: 01.03.2021 / Revised: 16.04.2021 / Accepted: 28.04.2021

(C) Husak S., 2021

https://doi.org/10.23939/as2021.01.042

\begin{abstract}
The former church and monastery of the Discalced Carmelites, present Greek Catholic Michael the Archangel Church, is one of the most unexplored sacred buildings of Lviv. Despite its historical importance to the town, the few surviving documents list only donations and royal privileges. This article refers to examples of other Carmelite churches, as well as Italian religious houses to try to explain the possible building process. Not only them but also the already existing convents of the city shaped its form, which is significant for locating its history within the local building tradition.
\end{abstract}

Key words: Discalced Carmelites, baroque architecture, mendicant order, architectural landscape of Lviv, Michael the Archangel Church.

\section{Problem statement}

Michael the Archangel Church, the cornerstone of which was laid in 1634, is not only the first example of a baroque sacred architecture fully decorated with frescoes in the western Ukrainian city of Lviv, but also an expression of a unique synthesis of the Spanish-Italian Carmelite architecture. Nevertheless, the building has not found much interest among historians yet. On the one hand, the small amount of preserved documents might have caused difficulties in reconstructing its history. On the other, its lack of architectural richness compared to the former Jesuit or Dominican churches can explain the scarcity of literary mentions.

Given the above, the article aims to shed light on the history of the religious building and refute the theories about the possible architect, based on one of the preserved documents. This happened during the second half of the 20th century, mostly because of the unfamiliarity of scholars with the sources mentioned above and the Discalced Carmelites itself, which as well has found little attention in the literature. On this basis, it is necessary to understand the broader historical context to make deeper research on the construction process and its influences.

\section{Analysis of research and publications}

The publications below, used for the research of the subject under analysis deal with a wide field of historical events and for a better allocation should be divided into two parts: source material and secondary literature. 
As for the first, the most important source materials about the order of the Discalced Carmelites are summarized in "The Carmelites. A history of the brothers of our Lady of Mount Carmel. ca. 1200 A.D. Until the Council of Trent" (1975) and "The Carmelites. The post Tridente period. 1550-1600" (1976) by the Carmelite monk J. Smet. Furthermore, the period relevant to the paper has been documented from the beginning of the order until 1718 in "Bullarium Carmelitanum plures complectes summorum pontificum constitutiones ad ordinem fratrum beatissimae, semperq[ue] virginis die genitricis Mariae de Monte Carmelo spectantes" $(1715,1718)$. Besides, the origins of the order's branch, the Discalced Carmelites, can best be reconstructed through the letters and autobiographical books "Libro de la Vida" (1565) and "Libro del fundazion" (1610) by the founder, T. de Ahumada.

Not only the history of the order is important for the article, but also the history of Lviv. That is why we are considering the town chronicles by B. Zimorowicz $(1835,1899)$ and J. T. Jozefowicz $(1854)$, who both lived during the time of construction of Michael the Archangel Church, to have a better understanding of this period. A large amount of source material can also be found in the work of historian and archivist D. Zubrzycki (1844). In his "Kronika Miasta Lwowa" a lot of documents from the Central Historical State Archive of Ukraine in Lviv illustrating the historical events of the city, which were not indicated in the chroniclers above, are mentioned. M. Kapral's "Privileges of the City of Lviv" (2010) is also of importance since it contains both the transcription of the privileges of the 15th -18 th centuries in Latin and the translation into Ukrainian.

However, the Central Historical State Archive of Ukraine in Lviv provides most of the materials on the building history of Michael the Archangel Church, although only a few documents are available because many manuscripts have either been lost or destroyed over the centuries. As a result, most of the information on the building standards of Carmelite churches and monasteries are taken from the "Constitutiones Fratrum Discalceatorum Congregationis S. Eliae Ordinis B[eatissi]mae Virginis Mariae de Monte Carmelo" (1631).

As for the secondary literature, the first attempt to give an overview of the construction history as well as the interior of Michael the Archangel Church is made by T. Mańkowski in his book "Dawny Lwow. Jego sztuka i kultura artystyczna" (1974). However, there is only the key analysis of the architectural style. Mańkowski's contemporary, B. Wanat, took over the attribution of the architect to Adam Pokora and his son Jan Pokorowicz from S. Łoza and M. Orłowicz in his work "Zakon Karmelitow bosych w Polsce. Klasztory Karmelito i Karmelitanek bosych 1605-1975" (1979) without further questions. On the contrary, interestingly enough, he treats the building history of Lviv's Discalced Carmelite Church in connection with other Carmelite architecture of the Kingdom of Poland based on archival documents. The next publication on the topic, "Michael the Archangel Church (the former Church of the Discalced Carmelites)" (2011, p. 30-37), was published only in 2011 - its author, J. Smirnov, only summarizes the two works discussed above. A critical view, published a year after, can be found in A. Betlej's work “Kościol p.w. Św. Michała Archanioła (Nawiedzenia Najśw. Panny Marii) i Klasztor oo. Karmelitow Trzewiczkowych (Pierwotne oo. Karmelitow Bosych)" (2012) where not only the architecture but also the frescoes are described in detail. Moreover, Betlej is also the first author who tries to show the influences of Italian art of the 16th and 17th centuries.

However, the list of the publications covering this topic is still very short and most of them lack a critical view on the subject, which leads to adopting questionable information without further research.

\section{The objective of the article}

The history of Michael the Archangel Church has been only fragmentarily handed down to these days. With the help of the sources from the Central Historical State Archive of Ukraine in Lviv, it is possible to reconstruct its building history only from the beginning of the 1630 s to 1642 , although this period is not described in detail either. The attempt to recreate it, therefore, based much more on the author's theories and observations than on archive materials. The hypotheses are built on the comparisons to the first Carmelite churches in Spain and later to some Roman baroque sacred architectures, both of which had an undoubted influence on Lviv. The most significant construction element, in this case, is the 
facade, which will be analyzed in detail and can fully illustrate the impact of the two architectural groups. On this basis, we will see that the city was not on the periphery of the architectonic events, as some historians claim, but it implemented the contemporary building tendencies.

Since the church was built during a politically unstable time, this fact should too be taken into consideration while looking at its construction and late restoration. The two city sieges by B. Khmelnytskyi in 1648 and 1655 and the later conquest of Lviv by Karl XII left their mark on the Carmelites' place of worship; it was severely damaged during the Swedish military operation.

The main achievements presented in the article are based on the critical confrontation with all given materials, which show different results if compared with other publications. For this reason, some old questions still cannot be answered, however, new horizons in the research are being opened up.

\section{Results and discussions}

\section{Building history of the church}

One of the Lviv chroniclers, I. Chodynicki, wrote in his "Wiedomość historyczna o fundacyach klasztorow zakonu karmelitańskiego (etc.)" that the Carmelites founded their first monastery in Lviv in the Galician Suburb in 1443, but left the city for many years soon after the convent was burned down by Tatars (Chodynicki, 1846, p. 26) However, the Ukrainian historian and archivist D. Zubrzycki, who relies on the source materials, claims in his work "Kronika miasta Lwowa" that the foundation took place a year later (Zubrzycki, 1844, p. 105; Zubrzycki, 2002, p. 94).

In 1599 the Archbishop of Lviv, J. Sulikowsky, wanted to bring the Carmelites back to the city. However, his plan failed due to the plague epidemic that began to rage in Krakow, where the friars were invited from and later spread in Lviv (Wanat, 1979, p. 55; BullCarm., 1768, p. 373; Zubrzycki, 2002, p. 227; CDIAL, f.52, op. 1, file no. 239., p. 3; Bevzo, O., 1970, p. 102).

Fourteen years later, the order received a permit from the General of the Italian Congregation, J. of Jesus Mary, to found a monastery in the city (CDIAL, f. 52, op. 1, file no. 237, p. 13; Wanat, 1979, p. 175). In 1614 the wooden friary in the Krakow Suburb behind the Krakow Gate was already built and received the patronage of Michael the Archangel (AKKr 338/453, p. 110; Wanat, 1979, p. 175). Anyway, the area proved to be very unfavourable: on the one hand, the convent was at the mercy of external dangers, as located outside the city walls and therefore difficult to be protected from raids; on the other, the topography was also disadvantageous, since the swampy area caused the poor health of the friars and the proximity of the river causing frequent floods. The Carmelites, therefore, wanted to move within the city walls as soon as possible to build a new monastery there CDIAL, f. 52, op. 1, file no. 237, p. 14.; CDIAL, f. 52, op. 1, file no. 237, p. 13; Metryka koronna 155, p. 169).

Unfortunately, any floor plans or elevations of the first building did not remain up to these days. The only possible illustration of the church, which falls under the description of the location, can be seen on the cityscape engraving "Civitates orbis terrarium" (Fig. 1) by F. Hogenberg (1617). However, it shows only a schematic representation of the facade, which resembles Lviv's old Dominican Church (1392) by its strict stepped gable. The further architectural influence certainly comes from Krakow, the city from which the Discalced monks were invited to Lviv. The similarities can be observed in the distinct vertical axis and stepped gables of the front of the Dominican Church and Corpus Christi Basilica (Fig. 2).

On December 20, 1625, Sigmund III issued a privilege allowing the Discalced friars to establish a new convent within the city walls (CDIAL, f. 52, op. 1, file no. 237, p. 19). 1631 to 1633 the Carmelites purchased land from the city residents on the so-called "Golushov Hill", not far from the eastern walls in the Galician Suburb. The acquisitions were approved on the 17th of October 1634 by the new king of Polish-Lithuanian Commonwealth, Władysław IV Vasa. During the following year, problems began to arise for the monks concerning the construction works and could not be solved quickly. In one of the acts of the Forty Townsmen from 1635, the friars were forbidden to buy the lands of Alexander Smidt that were needed for the building of a 
brickyard, a crucial part of the building process at that time. It went so far, that on the 19th of October the King issued a new privilege stating that the Discalced Carmelites on "Golushov Hill" shall not be opposed with malice and obstacles by the Townsmen in building the brick church and monastery. However, this process lasted for two more years. In 1637 after the day of St. Fabian and St. Sebastian the court decided to return the monks the full amount of money they had paid for the land. There was also a condition for the city to find another place for the brickyard for the Carmelites - a custom at that time, as it can be seen in the documents describing the building processes of the Benedictines and Dominicans. In the same year, the Discalced friars were given a suitable place, available to them for 15 years (CDIAL, f. 52, op. 1, file no. 237, p. 29, p. 40-43, p. 50, p. 54-55, p. 67, p. 71-75, p. 101-102, p. 118-121).
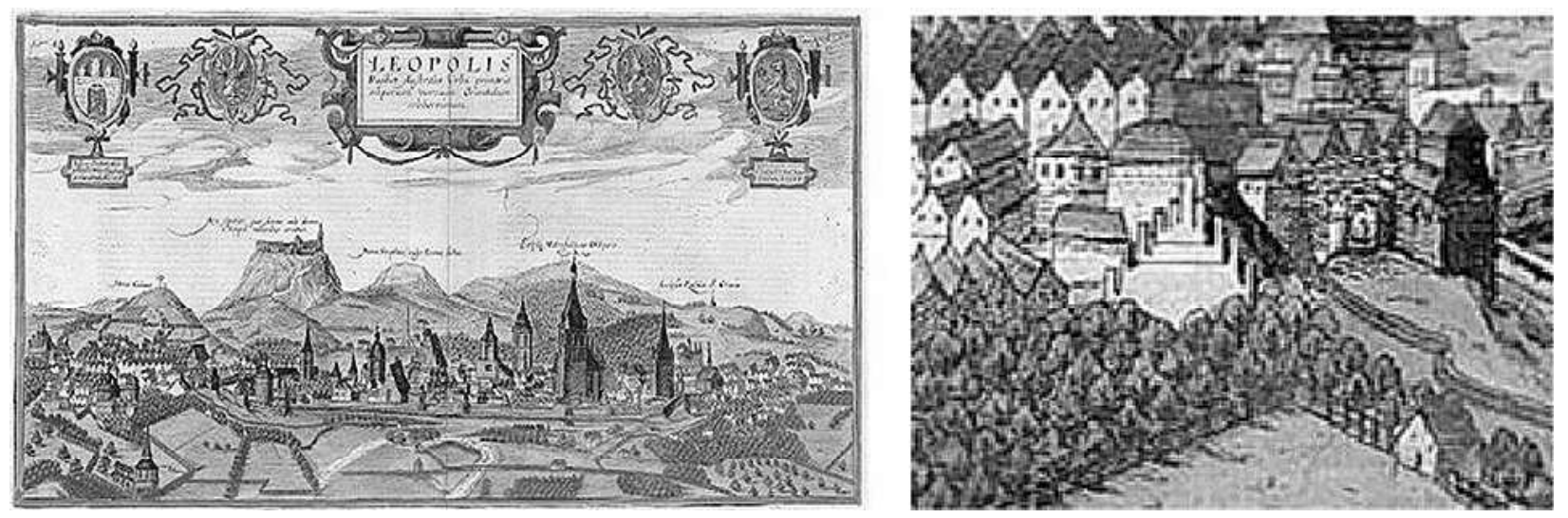

Fig. 1. F. Hogenberg, Civitates orbis terrarum, engraving, 1617. Source: Wikipedia, 2016
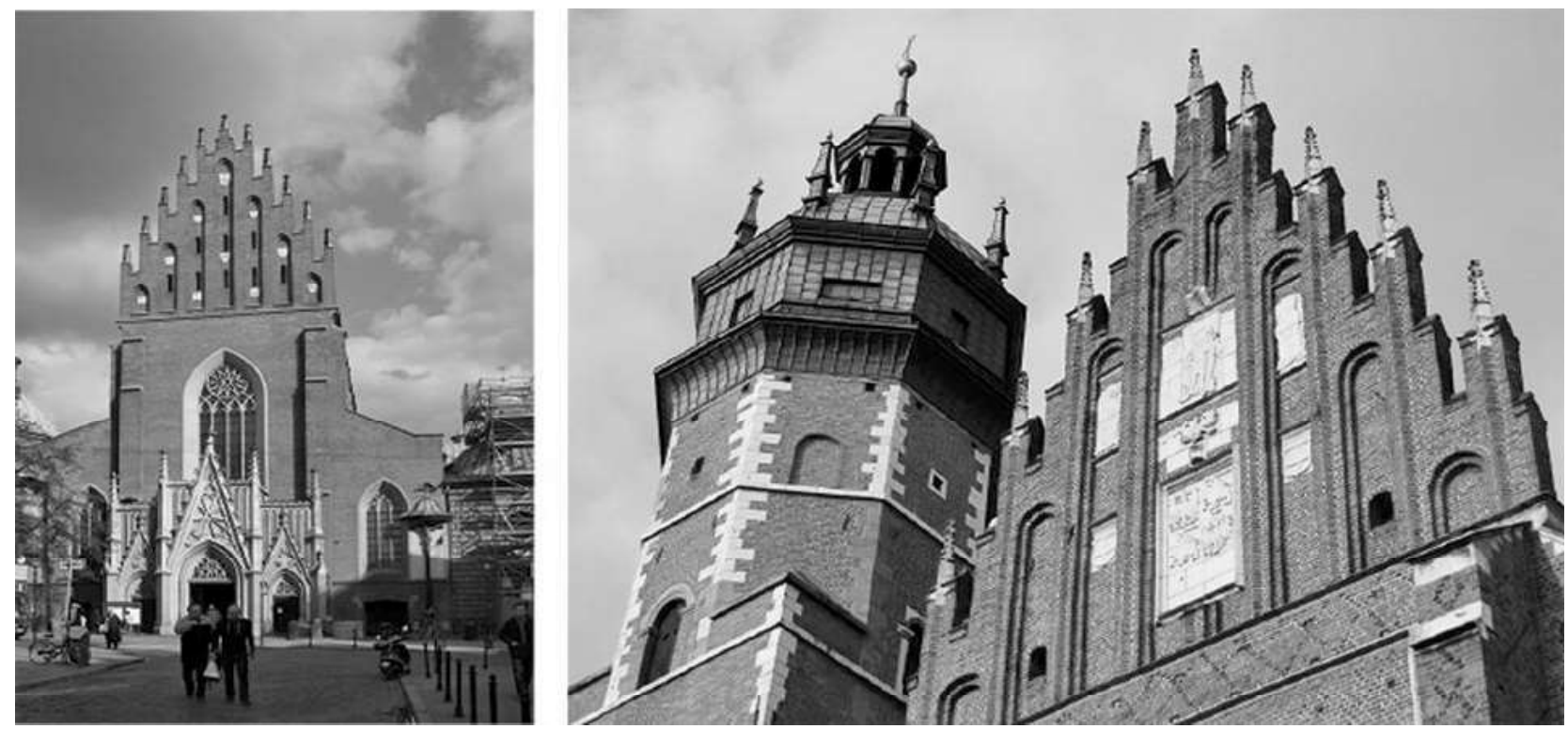

Fig. 2. Dominican Church, Krakow, built in the $14^{\text {th }}$ century (left) Corpus Christi Basilica, Krakow, built in 1385 (right)

Source: Wikipedia, 2016

Because the Discalced Carmelites did not have a brickyard during the first three years after the laying of the cornerstone, probably only the foundations were dug and scaffolds erected: in the archive documents nothing is reported about the progress of the construction works in 1634-1637. After the court proceedings were over, the building process of the new convent continued rapidly, making it possible for the monks to move into the newly erected church after only five years, in 1642. During the same year, the 
Discalced friars received permission from the magistrate to build a new city gate: it was needed because of the long distance between the convent and the two existent city gates. The construction work did not last long. In 1645 the Discalced Carmelite monastery was described as "ante portam orientalem noviter erectam" (CDIAL, f. 52, op. 1, file no. 237, p. 133, p. 142-145, p. 148).

The church and the monastery were erected during politically unstable times, as we can read in the consular records of 1655 that mention how badly the convent had been damaged in the course of the two city sieges by B. Khmelnytskyi (1648 and 1655). Although not described in detail, the damages were arguably tremendous: the Carmelites asked the magistrate to prolong their usage of the brickyard to be able to rebuild their property. This year also marks the end of any documentary mentions regarding the church and monastery (CDIAL, f. 52, op. 1, file no. 237, p. 162).

Besides, the further history of the convent should not go unnoticed, because of its importance to the later restoration processes. In 1784 the Galician Gouvernement received a royal decree according to which the monastery of the Discalced Carmelites was to be abolished in the course of the Josephine reform and the friars were to be moved to another one of their order. Two years later, the former Carmelite monastery was handed over to the Reformates. In 1789 the Calced Carmelites moved into the monastery along with the parish. In 1871 they changed the patronage of the church to the Visitation of the Virgin Mary and remained the owners of the convent until the beginning of the Second World War (AT-OeStA/AVA Kultus AK Katholisch 892 2, F 652.; Wanat, 1979, p. 186).
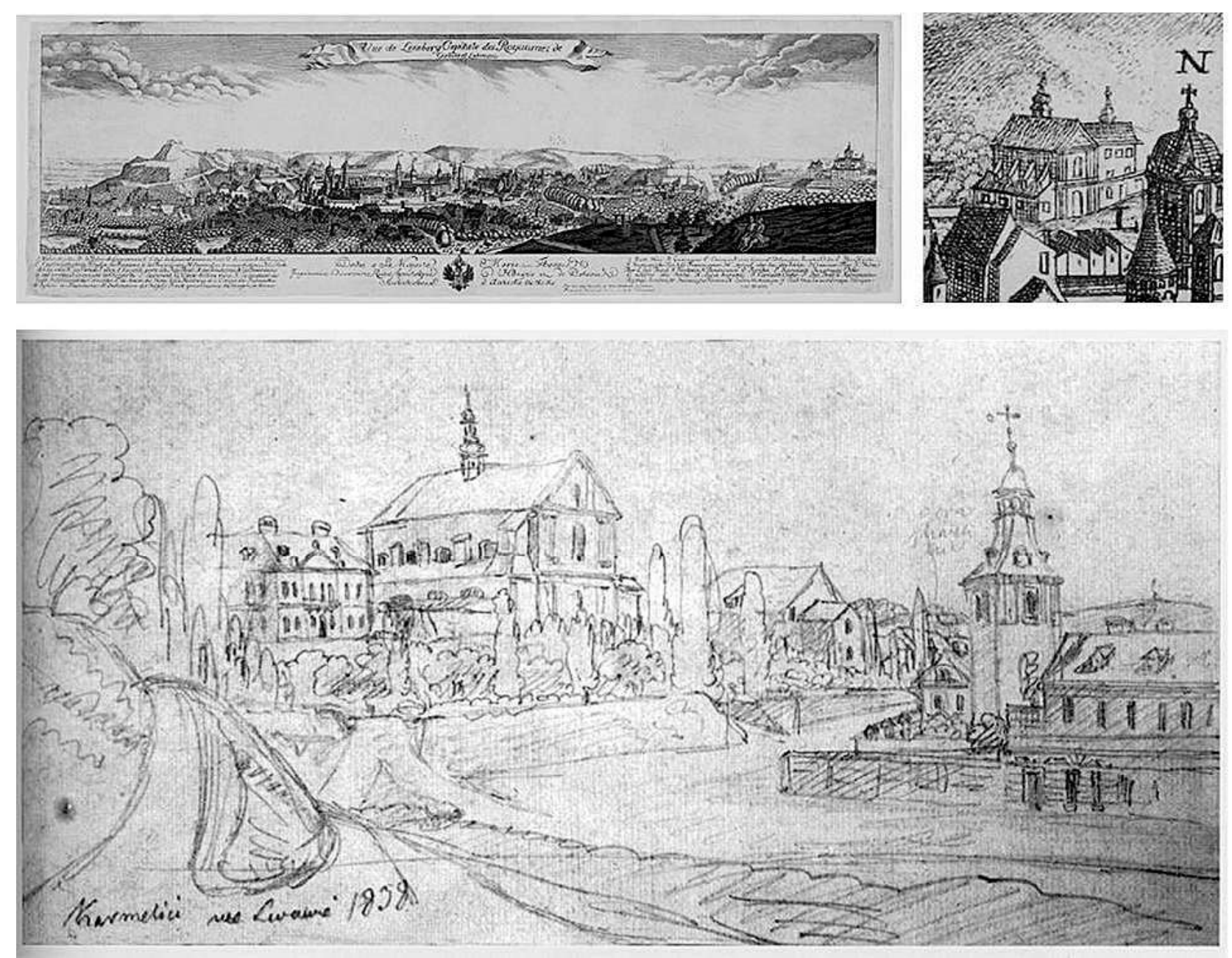

Fig. 3. F. Perneur, Cityscape of Lviv, engraving, 1775/77 (top)

K. W. Kielinsky, Church of Discalced Carmelites, view from the north, drawing, Lviv, 1838 (bottom) Source: Polona Archive, 2016; Betlej, A., Biernat, M., Kurzej, M., and Ostrowski, J. K., 2012 
After becoming acquainted with the historical background of Michael the Archangel Church, its building process, which ran relatively harmoniously, should be reconstructed at this point. This will be done based on comparisons between the cityscape by F. Perneuer from 1775/77 (Fig. 3), some ground plans and elevations, as well as a few drawings from the beginning of the 20th century.

\section{Exterior:}

1. F. Perneur's engraving from 1775/77: the first image of the church that survived to these days. Based on the quite accurately made miniature representation, one cannot see many changes in the building's silhouette from the 18th century until the construction of the two towers at the beginning of the 20th century.

2. K. W. Kiełinsky's drawing from 1838 (Fig. 3) and photographs from 1906 and 1911 (Fig. 4): the central part of the facade was designed almost exactly as it is preserved today. Even if the double pilasters are not precisely drawn at Kielinsky's image, their structure is still clearly visible and shows the Roman influence on the design of the church front.
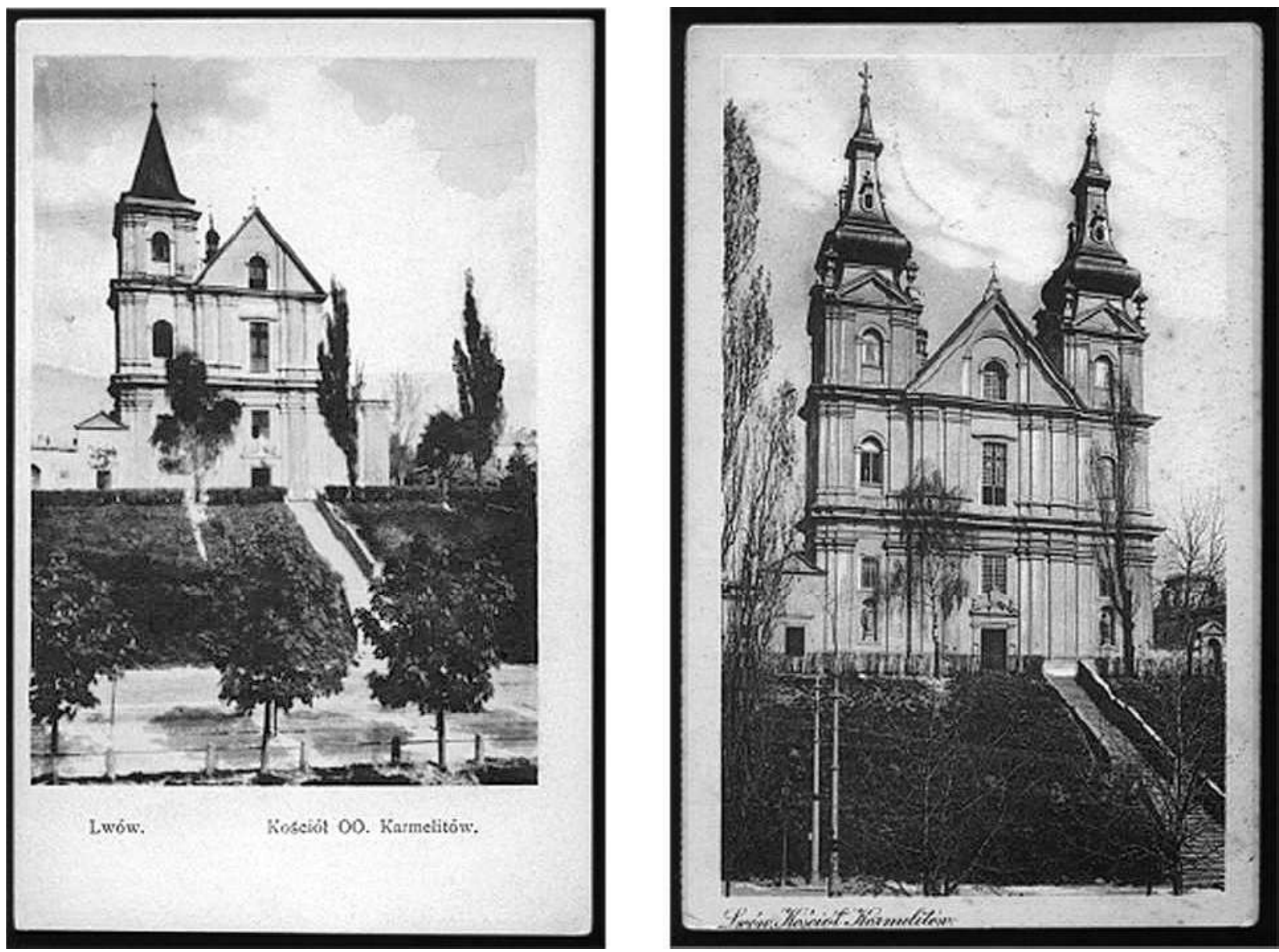

Fig. 4. Michael the Archangel Church, photography, Lviv, 1906 (left) Michael the Archangel Church, photography, Lviv, 1911 (right)

Source: Archive Polona, 2016

3. The facade plan from 1835 (Fig. 5) displays the ground plan and the elevation of the future towers. The double pilasters are present and a narrow cornice-like framing of the window on the second floor can be seen. However, the round-arched framing of the small opening in the triangular gable is missing. 
4. A. Vondrashka's facade plan from 1839 (Fig. 5) shows the future towers, whose construction begins with the northern tower in the same year and ends in 1906. The front's representation is almost as it remained until today. The round-arched framing of the small window in the triangular gable is missing, as it is on the plan from 1835. In this case, the framing could have been inserted during the "baroquezation" of the tower caps after 1906, since it appears for the first time in connection with them.
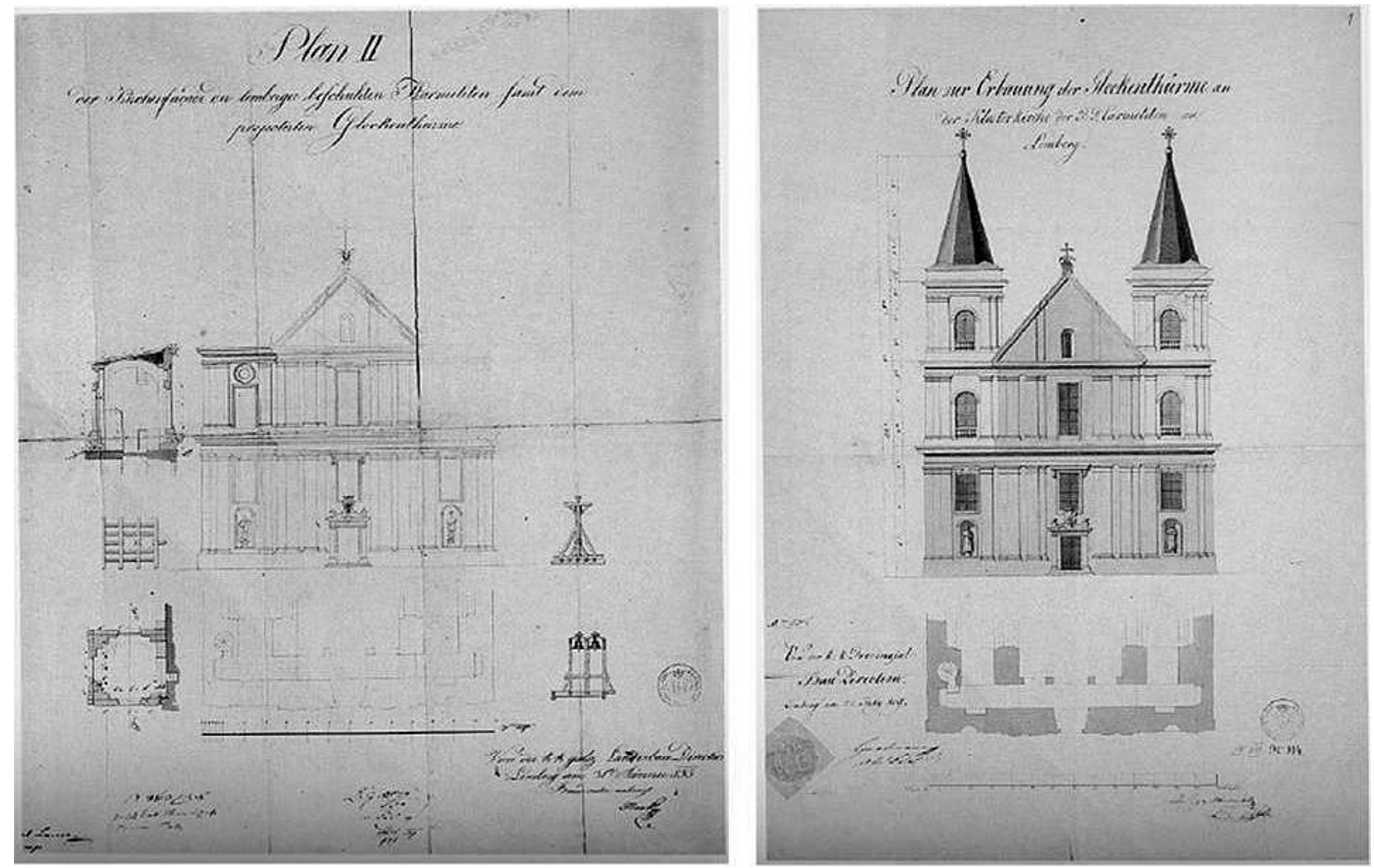

Fig. 5. Michael the Archangel Church, facade plan, Lviv, 1835 (left)

A. Vondrashka, Michael the Archangel Church, belfry towers plan, Lviv, 1839 (right)

Source: Betlej, A., Biernat, M., Kurzej, M., and Ostrowski, J. K., 2012

\section{Interior:}

1. Pillars Pillars supporting the gallery and pillars in the presbytery were originally decorated with stucco marble, which is visible on the photographs from 1939 (Fig. 6) and was probably removed shortly after when the church was transformed into an archive depot during the soviet time.

2. Niches in the chapel were presumably formed after the great restoration of the church during 1869-70. The dating is based on their form since these do not follow the architectural fresco. They occur in the first and second chapel on the southern and in the first and third one on the northern wall. It is unknown whether they also existed in the other two chapels for the southern wall was completely sealed in the 20th century, and the northern niche could be hidden behind the painting of the Holy Family. Their purpose was most likely intended for new altarpieces (Fig. 7).

3. Chapel windows: as can be concluded from the small thickness of the walls, all of them were bricked up from the inside (Fig. 8) during the same period. The project can probably be dated 1869-70 in view of the major style differences of the frescoes. The wall decorations from the late 19th century show the illusionistic painted architecture accomplished with great detail, while the originals from 1730-32 are large-scaled ornamental paintings on the window frames. 

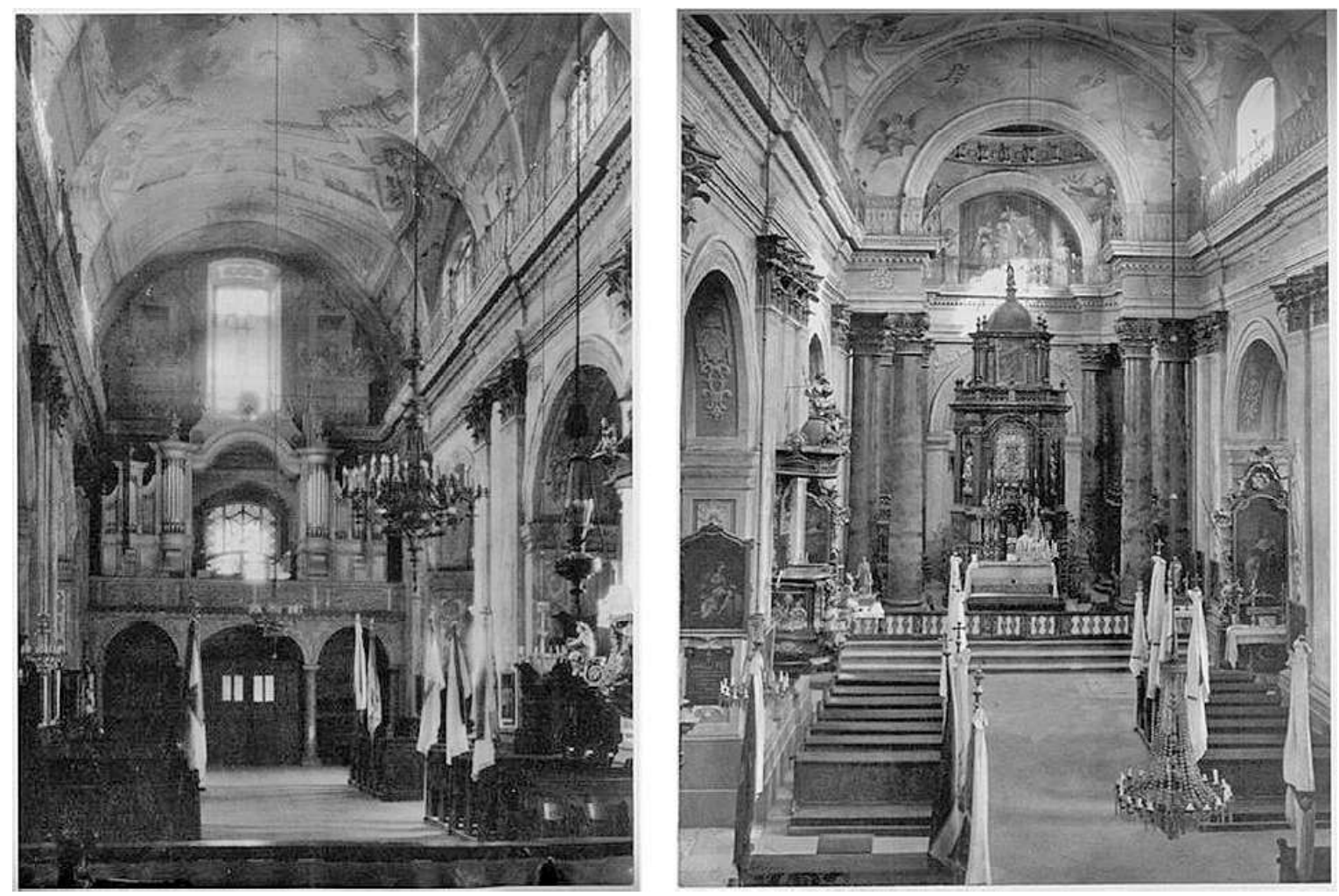

Fig. 6. Michael the Archangel Church, gallery, view from the west, photography, Lviv, 1939 (left) Michael the Archangel Church, presbytery, view from the east, photography, Lviv, 1939 (right) Source: Betlej, A., Biernat, M., Kurzej, M., and Ostrowski, J. K., 2012
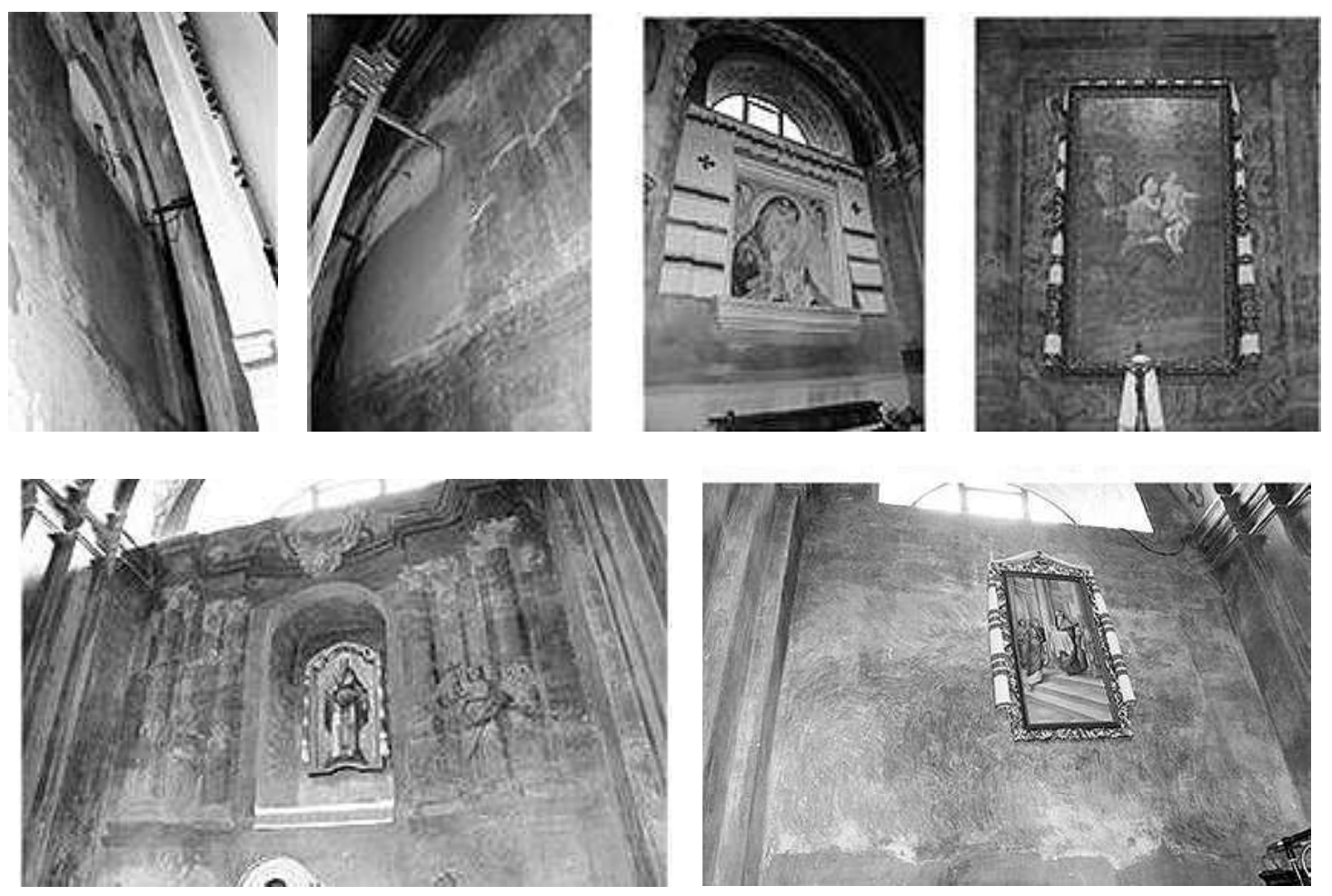

Fig. 7. Michael the Archangel Church, niches of the southern and northern chapels, photography, Lviv, 2016 (left)

Source: S. Husak, 2016 

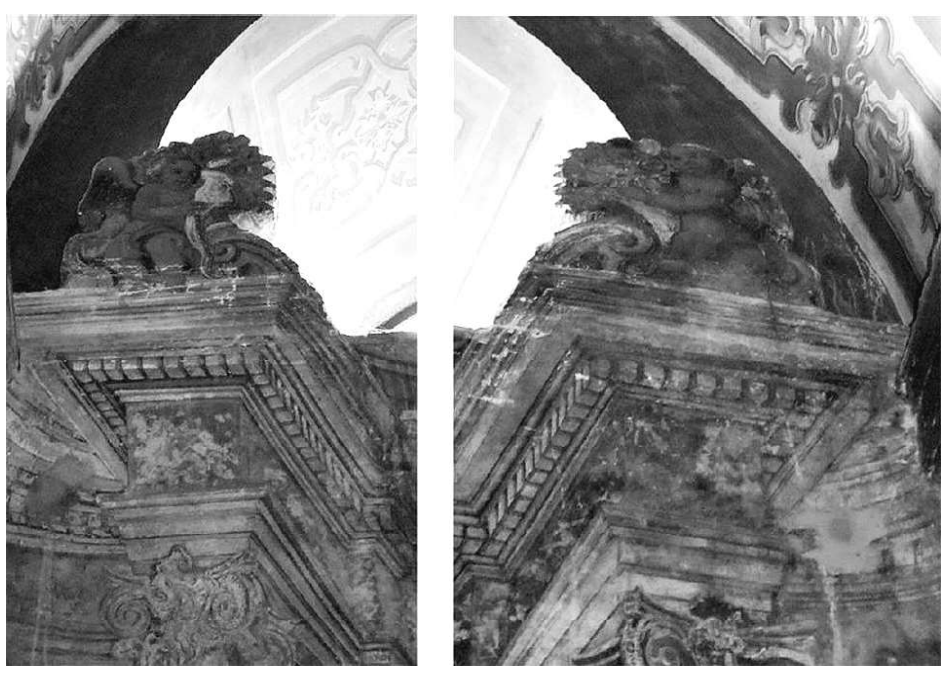

Fig. 8. Michael the Archangel Church, detail, first southern chapel from the west, photography, Lviv, 2016 (right) Source: S. Husak, 2016

\section{Architectural style of the Carmelites}

Carmelite churches from the $17^{\text {th }}$ and $18^{\text {th }}$ centuries form a self-contained building group. This could only be achieved with strict building norms: a precise prescription of measures, ground plans, elevations, and facade designs found in "Constitutiones Fratrum Discalceatorum Congregationis S. Eliae Ordinis $B{ }^{\text {mae }}$ Virginis Maria de Monte Carmelo" from 1631. Since the community lived in poverty and humility, the Generals decided that their churches should serve as images of these virtues: in this way the believers would perceive these values as soon as they enter the building. According to the "Constitutiones", the Provincial Definitors had two construction plans of a large and a small convent, which were approved by the General Definitors based on the economic situation and the number of monks in the particular city. Ergo, the width of the large churches was $9.6 \mathrm{~m}$ : Michael the Archangel Church, with its nave size of $10 \mathrm{~m}$, is one of them. Further building requirements were a prohibition of a dome - the Carmelites followed this in Lviv by making it visible only from the inside of the building, as it was done in S. Maria della Scala (1593) and St. Mary of Peace in Cologne (1643) (Fig. 9) - and exclusion of gold, marble or any other form of precious objects. (PP. Fortunatus a Jesu/ Beda a SS. Trinitate, 1968, p. 39-43; Wanat, 1979, p. 93-94., Vindelicorum, 1631, p. 75-76; p. 248; Wanat, 1979, p. 94-95)
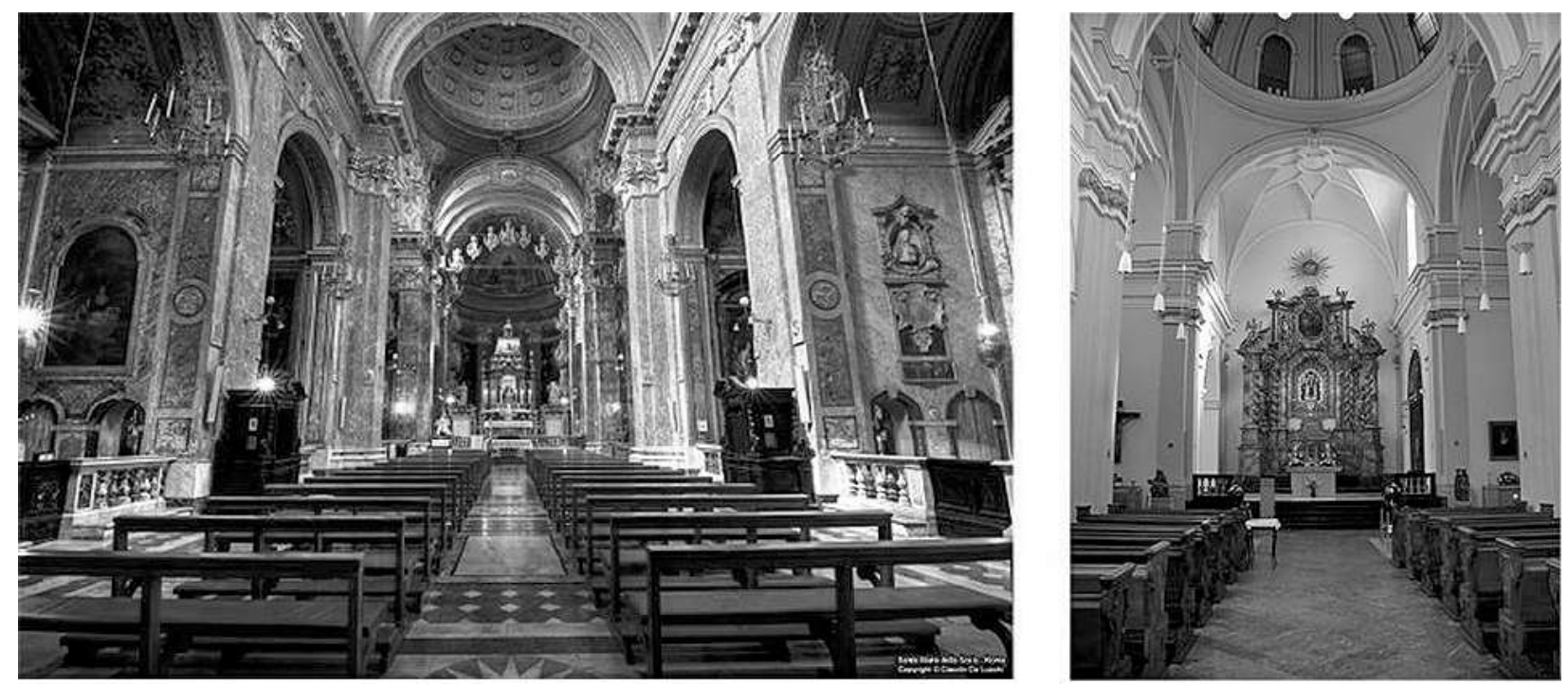

Fig. 9. Santa Maria della Scala, photography, Rome, built from 1539 (left)

St. Mary of Peace, photography, Cologne, built from 1643 (right)

Source: www.flickriver.com/photos/peronto/4528493977/(1.2.2021); Wikipedia, 2021 
The strong purism led to the development of a specific form of the facade, called by S. Sturm "the classical Carmelite facade", which served as the basis for all later Carmelite churches and became most widespread in the Iberian Peninsula (Sturm 2002, p. 121). Its silhouette was shaped in 1608 by F. de Mora, a student of Spain's most significant architect under Philip II, J. de Herrera, when he built the first church of Discalced Carmelites, S. José in Avila (Fig. 10) (Wilkinson- Zerner, 1993, p. 89, p. 117).
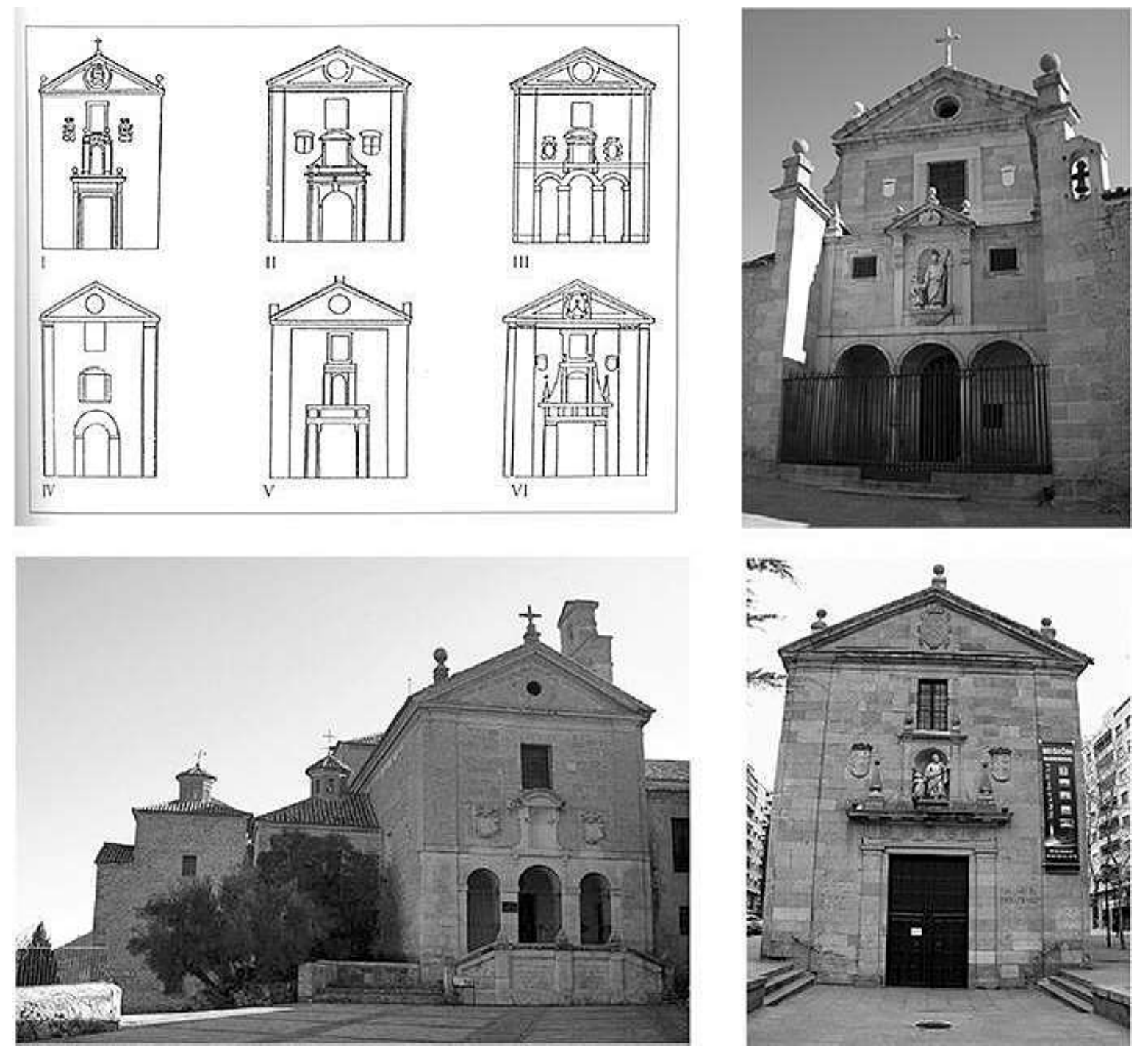

Fig. 10. S. Sturm, "the classical Carmelite facade”, plan, 2002 (top left)

F. de Mora, S. José, photography, Avila, built from 1608 (top right)

S. Pedro, photography, Pastrana, built from 1570 (bottom left)

S. Maria del Monte Carmelo, photography, Salamanca, built from 1612 (bottom right)

Source: S. Sturm, 2002; Wikiwand, 2016; www.carmelites.net/wp-content/uploads/Pastrana.jpg (1.2.2021); Wikipedia, 2016

The peculiarities of a "classical Carmelite facade" are a rectangle, framed by pilasters of the Tuscan order, crowned by a gable, with either an oeil-de-boeuf or the order's coat of arms in the centre. Under the gable, a rectangular window is placed. Underneath the window is a niche with a statue of the respective church patron, flanked either by coats of arms of the patrons or by other smaller windows. Often a single portal in the form of an aedicula is used in this type of facade, although a portico entrance may also occur, as one can see at S. Jose in Avila. Examples of the classical variant include the early Carmelite churches, such as S. Pedro (1570) in Pastrana and S. Maria del Monte Carmelo (1612) in Salamanca (Fig. 10). 
The strong Spanish impact can also be found in Michael the Archangel Church, where the austerity of the rectangular facade finished with a gable is visible. However, in contrast to the "classical Carmelite facade", there are two considerable differences: the division of the front by pilasters in Lviv is no longer flat but comes strongly to the fore; furthermore, the side chapels of the church are perceptible from the outside, which is never the case with the classical variant.

Yet, the greatest influence both on Lviv and Carmelite architecture is due to Rome. After the Reformation, a new, powerful movement of the Counter-Reformation was sought to restore the power of the Catholic Church to its full glory. From the middle of the $16^{\text {th }}$ century onwards, to better display the genius of the new religious buildings, the facade was more emphasized by its design than any other side; its best example: Il Gesù (1568). The Jesuit church had a great effect on the Carmelite architecture in central and eastern Europe, so that a "vignolesque facade" (Fig. 11), as it is called by S. Sturm after the architect G. Vignola (1507 - 1573), emerged. (Sturm, 2002, p. 122)

This type was adopted by the Carmelites, most probably because of the addition of wider side chapels, which no longer corresponded to the proportions of the "classical Carmelite facade". As well as in Il Gesù, the central part of the facade is divided into two floors by a cornice united by a gable and enclosing either the order's coat of arms or a window, as in the classical version. The newly added symmetrical side wings coincide with the design of the portal by incorporating niches and, in some cases, piercing windows to illuminate the side chapels, which are no longer closed to the nave but open directly to it, replacing the side aisles. This type of facade is mostly used for the sacred buildings of the male branch of the order, which were often intended as parish churches, e.g. St. Teresa in Vilnius (1633), the Church of the Immaculate Conception in Krakow and Lviv's Michael the Archangel Church (Fig. 11). (Sturm, 2002, pp. 122-126) Although Although we can only speculate about the original appearance of the building's front based on the above-mentioned engravings and drawings, we can certainly say that the strongly emphasized supporting elements, cornices, and entablatures, give the church a well readable geometrical order that divides the facade both horizontally and vertically.
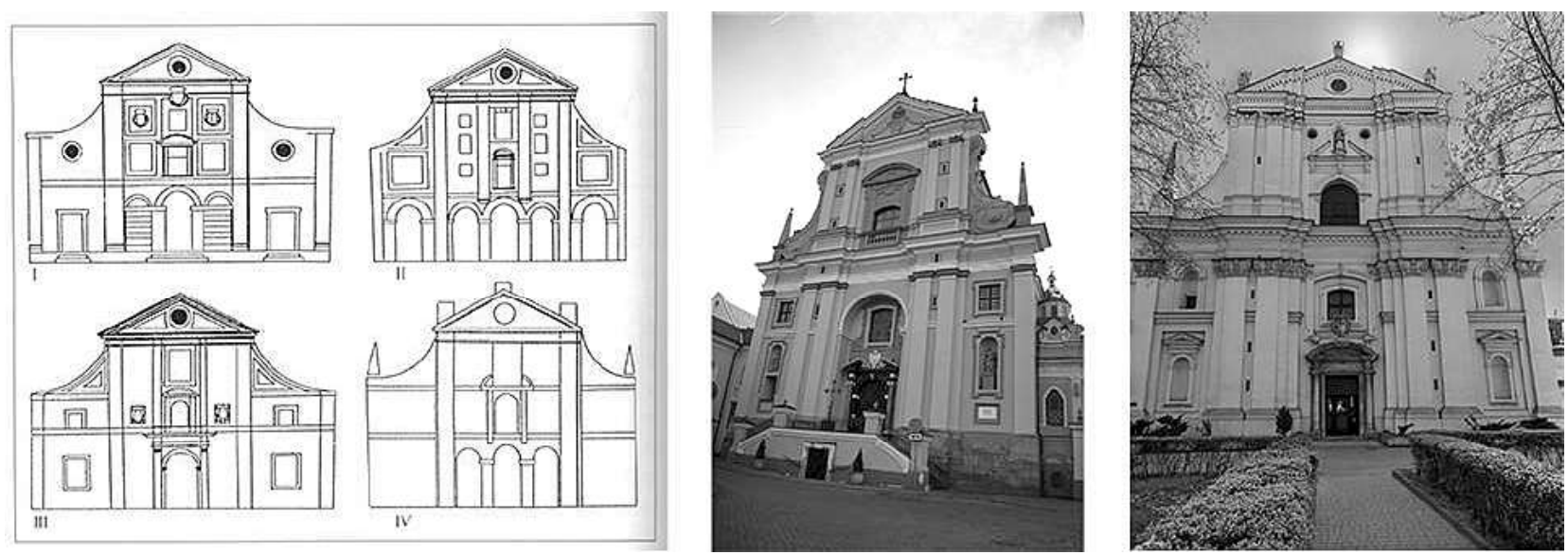

Fig. 11. S. Sturm, “vignolesque facade”, plan, 2002. (left); St. Teresa, photography, Vilnius, built from 1633 (middle); Church of the Immaculate Conception, photography, Krakow, built from 1634. (right)

Source: S. Sturm, 2002

Unlike Roman and Spanish sacred architecture, the church fronts of Discalced Carmelites of the former Polish province to which Michael the Archangel Church belongs also developed their specific feature: a window placed on each floor. The innovation is made on the ground level, where the opening is pierced as a substitute for the saint's figure above the portal. However, also the influence of Spain can be seen in Lviv in the placement of the window in the gable, wherein most Carmelite places of worship outside the Iberian Peninsula the order's coat of arms found its place. 
Even though the immense Spanish and Roman influences on Michael the Archangel Church cannot be overlooked, as shown by the above comparisons, the urban architecture of Lviv also had a great impact on the town's Discalced Carmelites. Its eclectic style, which combined Renaissance and Baroque forms, was essential for the construction, as the friars were always surrounded by it since their return to Lviv. Accordingly, the strong value of the architectural diversity of the city should not go unnoticed.

\section{Architectonic cityscape}

The city was always characterized by its multi-ethnicity: the German, Ruthenian, Armenian and Jewish populations lived together. Lviv was also the residence of three Christian bishops: Greek Catholic, Roman Catholic, and Armenian Apostolic. Therefore, there was the need for architects who could skillfully implement the churches of different religious denominations that had been arising since the middle of the $14^{\text {th }}$ century. They were brought to town mostly from the German-speaking countries and from the former Italian colonies. Nonetheless, the Renaissance established itself in the whole Kingdom of Poland only at the beginning of the $16^{\text {th }}$ century, although already widespread in Southern and Western Europe from the $15^{\text {th }}$ century. In Lviv, one of the reasons behind it could be linked to the Ruthenian owners, who did not want to fully neglect their old building tradition: hence the Italian architects commissioned to build the new Orthodox churches were to consider it. This resulted in a new, original, eclectic style that combined Italian Renaissance with Byzantine forms. (Mańkowsky, 1974, p. 98)

In this article, however, it is significant to see how the buildings constructed during the Renaissance and the beginning of the Baroque influenced Michael the Archangel Church. One of them is the Korniakt Tower, the belfry of the Dormition Church. It was built by Pietro di Barbona (? - 1588) from 1572 until ca. 1578 by order of a merchant from Crete, Konstanty Korniakt. (Zimorowicz, 1835, p. 221, p. 229; Mańkowsky, 1974, p. 108) The architect's use of the dividing elements such as lesenes and cornices on the facade in terms of decoration and not only as a support system is done here for the first time and also cannot be on Michael the Archangel Church. It can be assumed that the unknown Carmelite architect was inspired by Korniakt's building when the Discalced friars were given the lands opposite the Dormition Church and the tower (Fig. 12).
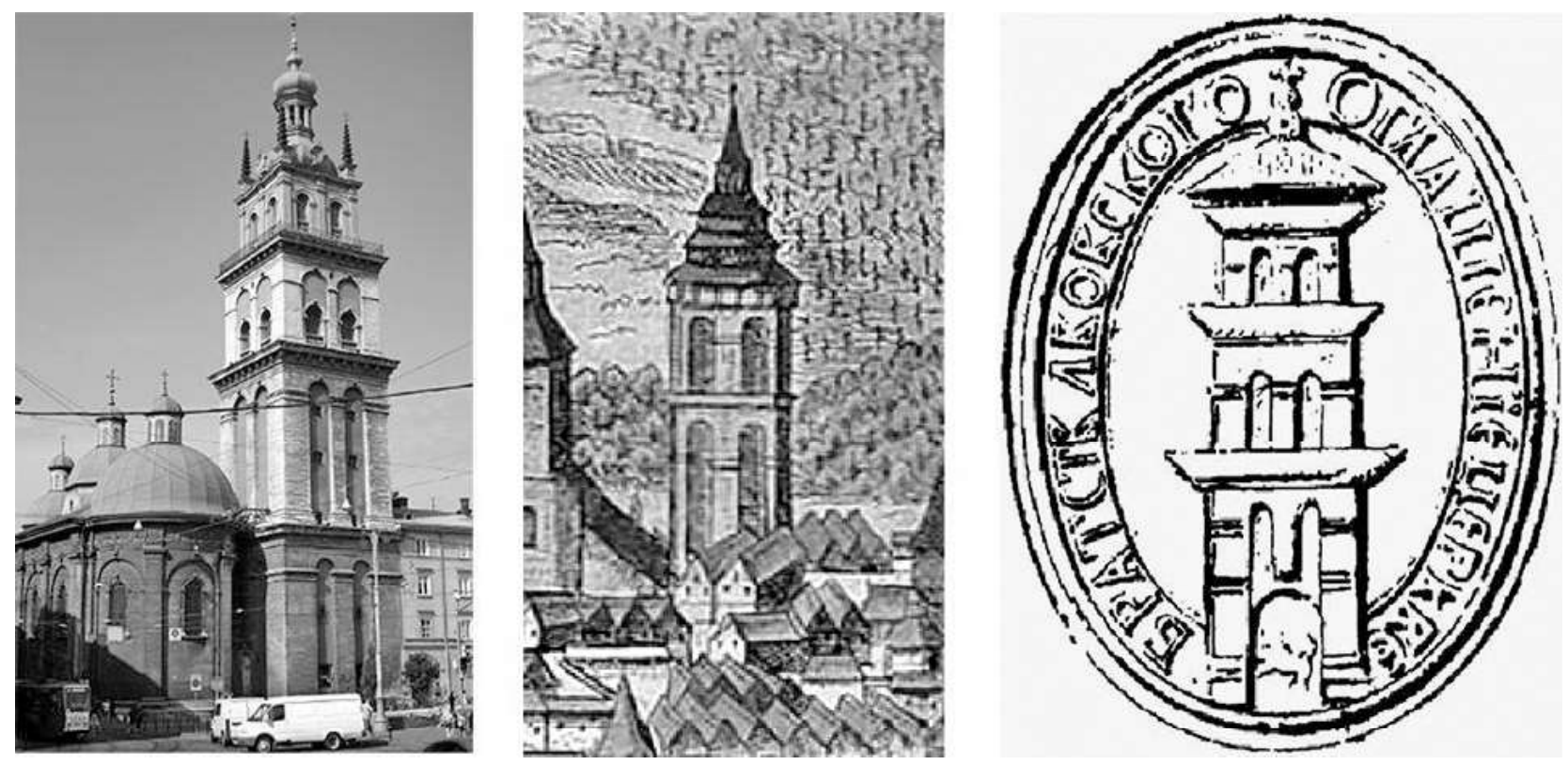

Fig. 12. Korniakt Tower and Dormition Church ("Wallachian Church”), photography, Lviv, built from 1572 (left); F. Hogenberg, Civitates orbis terrarum, detail of the Korniakt Tower, engraving, 1617 (middle); The original appearance of the Korniakt Tower, seal of the Stauropegia Brotherhood, seal (right)

Source: S. Husak, 2016; Mańkowski, 1974 
However, the strongest influence on the Renaissance architecture of Lviv and later Church of the Discalced Carmelites was made by Barbona's disciple, Paulo Dominici (? - 1618), also called Paul the Roman. Significant is his first duty: he was entrusted with the planning of the new Wallachian Church, preserved to this day, by the Stauropegia Brotherhood. Although Paul the Roman was the construction supervisor only until 1598, his successors continued to work on the building without any changes to the plan. Like the Karniakt Tower, Dominici's church exerted an impact on Michael the Archangel Church with its dividing elements. Analyzing both facades, the gliding gaze of the viewer is kept within the framework of the architecture. However, the pilasters of Tuscan order and cornices in both buildings already give away the structure of the interior. Since the entire architectural ensemble of the Dormition Church is strongly anchored in the Byzantine tradition, the Discalced Carmelites drew inspiration only from small quotations. (Mańkowsky, 1974, p. 121, p. 124; Shustova, Yu., 2009, p. 299; CDIAL, f. 129, op. 1, file no. 159; CDIAL, f. 52, op. 2, file no. 34, p. 250)

Of greater relevance for the order, however, was another of Dominici's buildings, the St. Andrew Church, which displays a strong influence of G. Vignola for the first time in Lviv. The beginning of the construction of the Benedictine monastery's church is dated 1600. Dominici was commissioned to build it according to the regulations of the order. After the plans were surveyed, the construction began, directed for about fourteen years by Paul the Roman. The architect's style is best seen both on the lower story of the facade and the southern side of the building (Fig. 13). As in the Wallachian Church, the front, including the southern wall, is divided by pilasters, which this time are doubled up to the apse. They frame the church facade of St. Andrew, as it was later done on Michael the Archangel Church, and clearly show the dimensions of the three naves of the basilica. The Benedictine building was completed in 1630, four years before the cornerstone of the new church of the Discalced Carmelites was laid. Because of Paulo Dominici's fame and the time frame in which the St. Andrew Church was built, it represented a significant example of the town's architecture. Thus, the Discalced friars were not excluded from its influence. Although the monks were supposed to follow strict building norms, they most likely also wanted to use some elements of Lviv's sacral architecture in their facade. Due to its strict forms the St. Andrew Church, especially the part of the building that was still built under Dominici, was the exact example of this. Although its front is still strongly anchored in the Renaissance, some quotations can be discovered in the Carmelites building, e.g. the narrow and high rectangle of the central part of the facade. However, the Discalced friars were above all inspired by the double pilasters and the cornices that roughly correspond to the width of the pilasters and do not visually weigh down the facade, as can be seen in S. Maria della Vittoria. After the addition of the two towers in Michael the Archangel Church, the influence of the Benedictine church became less visible at first sight, yet, the Renaissance forms, which came strongly to the fore, were not lost and were again emphasized by the pilasters of the towers, which come forward three times (Mańkowsky, 1974, p. 126, p. 130; Zimorowicz, 1899, p. 350).

Paulo Dominici's buildings were not the only ones that had an impact on the Discalced Carmelite. As already mentioned, according to Sturm the front of Michael the Archangel Church belongs to the type of "vignolesque facade", which underlines the great relevance of Il Gesù. However, it is necessary to ask whether the influence of the Jesuit architecture came directly from Rome or the monks were inspired by Lviv's Jesuit church (Fig. 14), whose construction was partly supervised by a Jesuit friar from Rome, Giacomo Briano (1586 - 1649). As well as the buildings of the Discalced Carmelites, the Jesuit churches were under the effect of their geographical location: Lviv was no exception. Unlike the mother church of the order, whose front can be perceived as a horizontal rectangle (with a small difference in dimensions between width and height), the S. Peter and Paul Church's facade is characterized by a vertical. Thus, the slender double pilasters and the higher basement emphasize the narrowness of the front. It strongly influenced the Discalced Carmelites. For them, it was easier to be persuaded by a Jesuit church already existing in the city they could see every day than to look to Rome. In this way, the type of "vignolesque 
façade" was preserved in its basic form, but some local uniqueness was adopted in the type of construction common to the Carmelites. Although the Discalced friars were mostly inspired by particular elements of Lviv churches, as pilasters, lesenes, or cornices, an alteration can be seen on the basis of the S. Peter and Paul Church: unlike the above-mentioned comparisons, the overall shape of the facade exerted an influence on Michael the Archangel Church (Mańkowsky, 1974, p. 218; Betlej/ Biernat/ Kurzej/ Ostrowsky, 2012, p. 75; ÖNB, Cod. 11988, p. 7, p. 131-132; Brinckmann, 1910, p. 7; Thullie, 1913, p. 48).
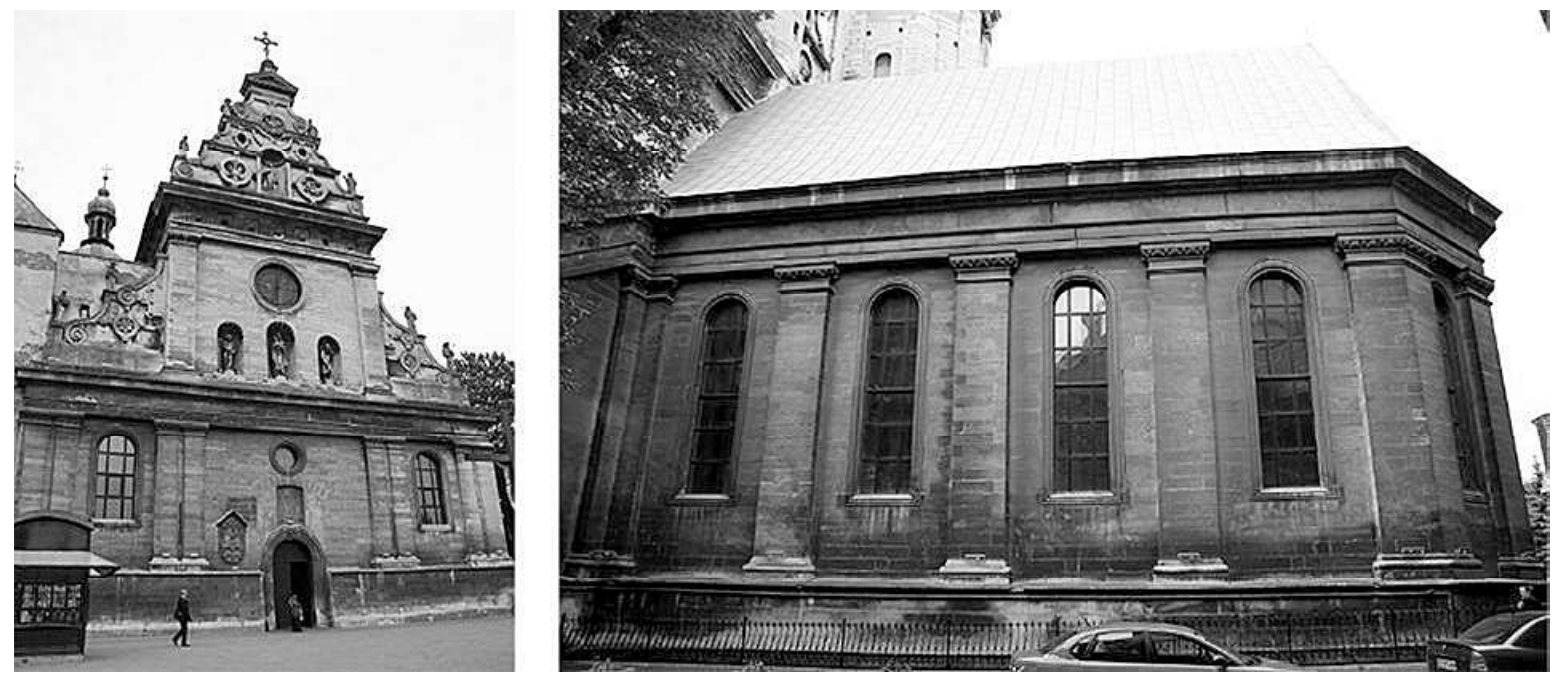

Fig. 13. P. Dominici, St. Andrew Church, photography, Lviv, built from 1600 (left) P. Dominici, St. Andrew Church, view from the south, photography, Lviv, built from 1600 (right) Source: S. Husak, 2016
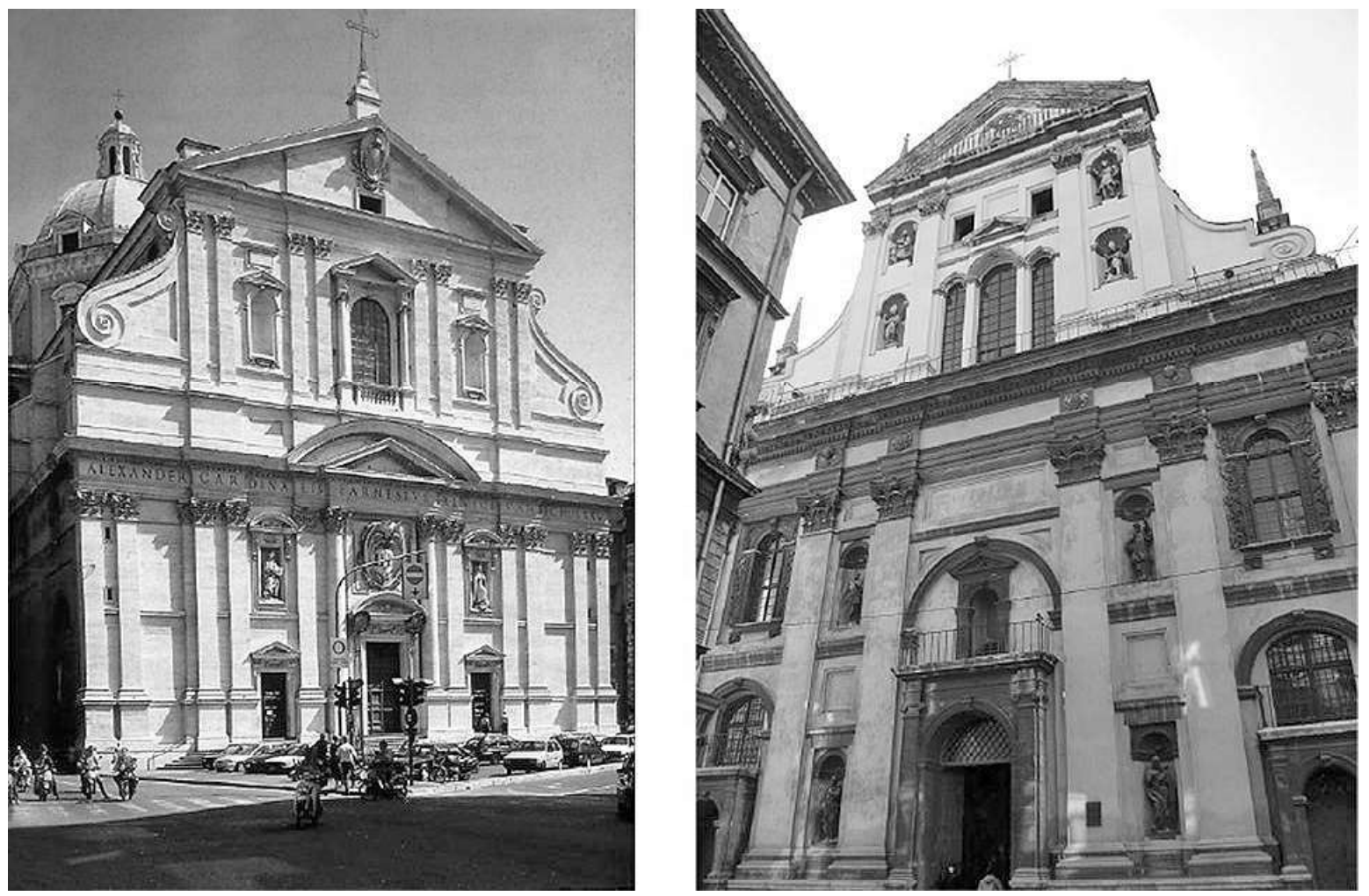

Fig. 14. G. Vignola, Il Gesù, photography, Rome, built from 1568 (left) S. Peter and Paul Church, photography, Lviv, built from 1610 (right) Source: UNIDAM Archive, 2016; S. Husak, 2016 


\section{Conclusions}

Michael the Archangel Church, which is one of the least researched sacred buildings from the Baroque period in Lviv, represents one of the best examples of a synthesis of Spanish and Italian Carmelite architecture. Unfortunately, this has remained unnoticed by scholars until today. Since the church was built during a difficult period of uprisings and wars, its construction history is a sign of the persistence of the Discalced Carmelites, who, despite the problematic financial situation, built a convent near the city walls.

One of the most challenging questions is of course the identification of the builder. Because of the lack of archival documents, the name of the architect remains unknown, regardless of previous assumptions by B. Wanat, S. Loza, and M. Orłowicz is Jan Pokorowicz. Taking into consideration the influences mentioned above, it can be assumed that the architect must have been most probably a Carmelite monk coming from Italy. This thesis accounts for an architecture strongly oriented to Rome, which would have a different form without knowledge of the works of G. Vignola or G. B. Soria. Although the church was restored several times in the $17^{\text {th }}$ and later in the $18^{\text {th }}$ century owing to the political situation, its appearance hardly changed. The facade towers added in 1906-1911 represent the only major change to the building: at its core it remains a homogeneous Baroque structure. The architectural influence came not only from Italy but also from Lviv itself. Most likely, the Discalced Carmelites wanted to build a church that would seamlessly fit into the architectural landscape of the city. The unknown builder succeeded in doing so with the help of architectonic elements such as pilasters and cornices, which most probably were introduced to the town's architecture in the $16^{\text {th }}$ century by Pietro di Barbona and Paul the Roman.

Michael the Archangel Church opens a rich research field between the Italian, especially Roman, architecture and Lviv. This has not been considered by researchers until today, as can be best seen in the brief mentions of the studied building in the literature on Lviv architecture. This article attempts to look behind a curtain, even though the sparse historical documentation does not allow more in-depth source research. However, there is hope that over time some documents, as well as critical publications on this subject, will appear.

\section{References}

AKKr 338/453.

AGAD, Metryka koronna 155.

AT-OeStA/AVA Kultus AK Katholisch 892 2, 1787-1825. Karmeliter in genere, in Lemberg, Milatyn, Sosiadowice, Trebowla, Wiszina, Zagorze.

Betlej, A., Biernat, M., Kurzej, M., and Ostrowski, J. K., 2012. Materiały do dziejów sztuki sakralnej na ziemiach wschodnich dawnej Rzeczypospolitej, Kościoły i klasztory Lwowa z okresu przedrozbiorowego, 20. Krakow.

Bevzo, O., 1970. L'vivs'kyy litopys i Ostroz'kyy litopysets'. Kyiv

Brinckmann, A. E., 1970. Handbuch der Kirchen Roms, Die Kirchen innerhalb der Mauern Roms, 2. Vienna.

Bullarium Carmelitanum plures complectes summorum pontificum constitutiones ad ordinem fratrum beatissimae, semperq[ue] virginis die genitricis Mariae de Monte Carmelo spectantes, 1, 1715. Rome.

Bullarium Carmelitanum plures complectes summorum pontificum constitutiones ad ordinem fratrum beatissimae, semperq[ue] virginis die genitricis Mariae de Monte Carmelo spectantes, 2, 1718. Rome.

Chodynicki, I., 1846. Wiadomość historyczna o fundacyach klasztorów zakonu karmelitańskiego, niegdyś $w$ Polsce $i$ Litwie, późniéy pod panowaniem Austryi, Rossyi, Pruss zostających. Lviv.

De Ahumada, T., 1565. Libro de la Vida.

De Ahumada, T., 1610. Libro del fundazion.

Husak, S., 2016. Die Kirche des Erzängels Michael und das Karmeliterkloster in Lwiw. Master Thesis, University of Vienna, Vienna.

Jósefowicz, J. T., 1854. Kronika miasta Lwowa : od roku 1634 do 1690 : obejmująca w ogólności dzieje dawnej Rusi Czerwonej: a zwłaszcza Historya arcybiskupstwa lwowskiego w tejże epoce / napisana spótcześnie w języku łacińskim przez J. Tomasza Józefowicza. Lviv.

Kapral', M., 2010. Pryvileyi L'vova. L'viv.

Mańkowski, T., 1974. Dawny Lwów. Jego sztuka i kultura artystyczna. London. 
ÖENB, Cod. 11988, Historia collegii leopolinensis Societatis Jesu manu priopria R(everendi) P(atris) Matthiae Wielewicz pro tunc rectoris dilligentissime collecta et decripta ad annum 1665, quo anno obdormavit in Domino.

PP. Fortunatus a Jesu and Beda a Ss. Trinitate OCD, 1968. Constitutiones Carmelitarum Discalceatorum. Rome.

Smet, J., 1975. The Carmelites. A history of the brothers of our Lady of Mount Carmel. Ca. 1200 A.D. Until the Council of Trent. Rome.

Smirnov, Yu., 2011. Khram Svyatoho Arkhystratyha Mykhayila (kolyshniy kostel karmelitiv bosykh). Halyts'ka Brama, 56, S. 30-37.

Sturm, S., 2002. L'architettura di Carmelitani scalzi in età barocca. L'Eremo di Montevirginio e la tipologia del Santo Deserto, 3, Rome.

Thullie, C., 1913. O kosciołach lwowskich czasów odrodzenia. Lviv.

Vindelicorum, A., 1631. Constitutiones Fratrum Discalceatorum Congregationis S. Eliae Ordinis B.mae Virginis Maria de Monte Carmelo, Augsburg.

Wanat, B. J., 1979. Zakon Karmelitów bosych w Polsce. Klasztory Karmelitów I Karmelitanek bosych $1605-1975$. Krakow.

Wilkinson-Zerner, C., 1993. Juan de Herrera. Architect to Philip II of Spain. New Haven.

Shustova, Yu., 2009. Dokumety l'vovskogo Uspenskogo stavropigiyskogo bratstva (1586-1788). Source study. Moscow..

Zimorowicz, B., 1835. Historya miasta Lwowa, Królestw Galicyi I Lodomeryi stolicy z opisaniem dokładnem okolic I potróynego oblęźenia. Lviv.

Zimorowicz, B., 1899. Pisma do dziejów Lwowa odnoszące się z polecenia reprezentacyi miasta. Lviv.

Zubrzycki, D., 2002. Kronika miasta Lwowa. Lviv.

CDIAL, f.52, op. 1, file no. 239.

CDIAL, f. 52, op. 1, file no. 237.

CDIAL, f. 129 , op. 1 , file no. 159.

CDIAL, f. 52, op. 2, file no. 34 .

\section{Соломія Гусак}

Випускник кафедри історії мистецтв Віденський університет, Відень e-mail: solomia_husak@yahoo.com

ORCID 0000-0002-7922-7405

\section{КОСТЕЛ КАРМЕЛІТІВ БОСИХ У ЛЬВОВІ ТА АРХІТЕКТУРНИЙ СТИЛЬ}

Анотація. Колишній костел та монастир кармелітів босих, а теперішня греко-католицька церква Архистратига Михаӥла, $\epsilon$ однією з найменш досліджуваних сакральних споруд Львова. Незважаючи на його історичну иінність для міста, в небагатьох документах, які збереглися до наших днів, перераховані лише пожертви та королівські привілеї: у иій статті за допомогою прикладів інших костелів кармелітів, а також італійських святинь, буде зроблена спроба відтворення можливого процесу його будівниитва. Не лише вони, а й вже існуючі монастирі та храми міста сформували вигляд костелу львівських кармелітів, що є важливим для розуміння $і$ локалізацї його історії в місиевій будівничій традииіï.

Ключові слова: кармеліти босі, барокова архітектура, жебручий орден, архітектурний ландиафт Львова, костел Архистратига Михаїла 